\title{
Polymorphism of the CYP1A1*2A gene and susceptibility to lung cancer in a Brazilian population ${ }^{* * * *}$
}

\author{
0 polimorfismo do gene CYP1A1*2A e a suscetibilidade \\ ao câncer de pulmão na população brasileira
}

\author{
Helen Naemi Honma, Eduardo Mello De Capitani, Aristóteles de Souza Barbeiro, \\ Daniel Botelho Costa, André Morcillo, Lair Zambon
}

\begin{abstract}
Objective: To estimate and compare the frequency of CYP $1 \mathrm{~A} 1 * 2 \mathrm{~A}$ gene polymorphisms in a Brazilian population and determine the possible contribution of these genetic variations to lung cancer risk. Methods: The study population included 200 patients with lung cancer, and the control group consisted of 264 blood donors. Genomic DNA was obtained from peripheral blood samples. The PCR-RFLP method was used for analysis of the CYP $1 \mathrm{~A} 11^{*} 2 \mathrm{~A}$ gene. Results: There was no statistically significant difference between the lung cancer patients and the controls in terms of the distribution of CYP1A $1 * 2 A$ polymorphisms $(p=0.49)$. A multivariate logistic regression model analysis by ethnic group revealed that, within the lung cancer group, the CYP1A $1{ }^{*} 2 \mathrm{~A}$ genotype CC plus TC was more common among the African-Brazilian patients than among the White patients (adjusted $\mathrm{OR}=3.19$; 95\% Cl: 1.53-6.65). Conclusions: The CYP1A1*2A gene cannot be linked with lung cancer risk in Brazilian patients at this time. Larger epidemiologic studies are needed in order to establish whether the CC plus TC polymorphism increases the risk of lung cancer in African-Brazilians.
\end{abstract}

Keywords: Lung neoplasms; Polymorphism, genetic; Metabolism.

\section{Resumo}

Objetivo: Estimar e comparar a frequência do gene polimórfico CYP1A1*2A na população brasileira e determinar uma possivel contribuição dessas variações genéticas no risco para câncer de pulmão. Métodos: A população estudada incluiu 200 pacientes com câncer de pulmão e o grupo controle consistiu em 264 doadores de sangue. 0 DNA genômico foi obtido de amostras de sangue periférico. 0 método usado para a análise do gene CYP1A $1 * 2 \mathrm{~A}$ foi a PCR-RFLP. Resultados: A distribuição do gene CYP1A $1{ }^{*} 2 \mathrm{~A}$ polimórfico não foi estatisticamente diferente entre os pacientes com câncer de pulmão e os controles $(p=0,49)$. Uma análise multivariada utilizando-se o modelo de regressão logística por grupo étnico revelou uma maior frequência do genótipo CC + TC do gene CYP1A $1 * 2 A$ no grupo de pacientes afro-brasileiros do que no grupo de pacientes caucasoides com câncer de pulmão (OR ajustada $=3,19$; 1 C95\%: 1,53-6,65). Conclusões: 0 gene CYP1A1*2A não pode ser associado ao risco de câncer de pulmão nesta amostra de pacientes. Um extenso estudo epidemiológico é necessário para estabelecer se os genótipos CC + TC aumentam o risco de câncer de pulmão em afro-brasileiros.

Descritores: Neoplasias pulmonares; Polimorfismo genético; Metabolismo.

\footnotetext{
* Study carried out at the Universidade Estadual de Campinas - Unicamp, State University at Campinas - School of Medical Sciences, Campinas, Brazil.

Correspondence to: Helen Naemi Honma. Rua Tessália Vieira de Camargo, 126, Barão Geraldo, CEP 13083-970, Campinas, SP, Brasil.

Tel 5519 3521-7907. E-mail: helennaemi@ig.com.br

Financial support: This study received financial support in the form of a grant from the Fundação de Amparo à Pesquisa do Estado de São Paulo (FAPESP, Foundation for the Support of Research in the State of São Paulo; grant no. 2004/13519-5).

Submitted: 20 January 2009. Accepted, after review: 5 March 2009.

** A versão completa em português deste artigo está disponível em www.jornaldepneumologia.com.br
} 


\section{Introduction}

Worldwide, lung cancer is the leading cause of cancer-related deaths in men and women. Although the primary etiology (smoking) is well established, it is also known that some smokers develop lung cancer, whereas others do not. ${ }^{(1)}$ Therefore, the use of molecular epidemiology techniques in the study of lung cancer has received widespread attention.

The cytochrome P450 1A1, a key enzyme in carcinogen metabolism, is involved in the activation and conjugation of the constituents of tobacco. ${ }^{(2)}$ By virtue of its polymorphic regulation, the CYP1A1 gene has shown promise as a biomarker for susceptibility to certain malignancies, lung cancer in particular. ${ }^{(3)}$

The first mutation detected (called $\mathrm{m} 1$ ) was a T-to-C transition 1194 bp downstream of exon 7 , creating a new Mspl cleavage site. ${ }^{(4,5)}$ This mutation was found to be overrepresented among lung cancer patients in Japan. ${ }^{(6)}$

Protein expression of the variant CYP1A1 genotype can result in increased formation of carcinogenic metabolites due to the hyperactivity of this phase I enzyme. In addition, the subsequent detoxification of reactive metabolites of these carcinogens can be hampered by the absence of functional phase II enzymes such as GSTM1 and GSTT1, which might play a role in the initiation or progression of lung cancer. ${ }^{(7)}$

Individuals carrying the $\mathrm{CYP} 1 \mathrm{~A} 1^{*} 2 \mathrm{~A}$ or CYP $1 A 1^{*} 2 B$ allele present increased activity of the respective enzymes isoforms, which might contribute to increasing levels of electrophilic metabolites derived from polycyclic aromatic hydrocarbons (PAHs). Smokers carrying the $\mathrm{CYP} 1 \mathrm{~A} 1{ }^{*} 2 \mathrm{~A}$ or $\mathrm{CYP} 1 \mathrm{~A} 1^{*} 2 \mathrm{~B}$ allele present increased levels of PAH-DNA adducts and higher rates of p53 mutations. ${ }^{(8,9)}$ Drakoulis et al. ${ }^{(10)}$ showed the prevalence of these alleles to be lower in a population of German lung cancer patients than in a population of Japanese lung cancer patients $\left(7.3 \%\right.$ vs. 33.2\%). ${ }^{(6)}$ The prevalence of the variant genotype is higher among Asians $^{(11)}$ than among Whites ${ }^{(12)}$ and AfricanAmericans. ${ }^{(13)}$

The aim of the present study was to estimate and compare the frequency of CYP $1 \mathrm{~A} 1 * 2 \mathrm{~A}$ gene polymorphisms in a Brazilian population and to determine the possible contribution of these genetic variations to lung cancer risk.

\section{Methods}

The study population included 200 patients with lung cancer (144 men and 56 women; mean age: $64.0 \pm 9.7$ years) evaluated in the Pulmonology Department of the State University at Campinas Hospital das Clínicas, located in Campinas, Brazil, between January of 2004 and December of 2006.

As a control group, 264 blood donors (160 men and 104 women) were recruited from the same hospital. All procedures were carried out according to institutional guidelines, and the study was approved by the Human Research Ethics Committee of the State University at Campinas Hospital das Clínicas (CEP 620/2004). All participants gave written informed consent.

In all cases, the diagnosis of lung cancer was confirmed by histological evaluation of tumor biopsies. Clinical data and smoking history data were collected from patient charts.

Genomic DNA was obtained from peripheral blood samples (12 mL) collected into ethylen-

Table 1 - Age, gender, race, smoking status, histology and staging characteristics of the patient and control groups.

\begin{tabular}{|c|c|c|c|}
\hline \multirow[t]{2}{*}{ Characteristic } & Patients & Controls & \multirow[t]{2}{*}{$\mathrm{p}$} \\
\hline & $(n=200)$ & $(n=264)$ & \\
\hline \multicolumn{4}{|l|}{ Age, n (\%) } \\
\hline$<64$ years & $100(50.0)$ & $250(94.7)$ & \multirow[t]{2}{*}{$<0.0001^{*}$} \\
\hline$\geq 64$ years & $100(50.0)$ & $14(5.3)$ & \\
\hline \multicolumn{4}{|l|}{ Gender, n (\%) } \\
\hline Male & $144(72.0)$ & $160(60.6)$ & \multirow{2}{*}{$0.0106^{*}$} \\
\hline Female & $56(28.0)$ & $104(39.4)$ & \\
\hline \multicolumn{4}{|l|}{ Ethnicity, n (\%) } \\
\hline White & $158(79.0)$ & $215(81.4)$ & \multirow[t]{2}{*}{0.5122} \\
\hline African-Brazilian & $42(21.0)$ & $49(18.6)$ & \\
\hline \multicolumn{4}{|l|}{$\begin{array}{l}\text { Smoking status, } \\
\mathrm{n}(\%)\end{array}$} \\
\hline Smoker & $179(89.5)$ & 86 (32.6) & \multirow[t]{2}{*}{$<0.0001^{*}$} \\
\hline Nonsmoker & $21(10.5)$ & $178(67.4)$ & \\
\hline \multicolumn{4}{|l|}{ Histology, n (\%) } \\
\hline NSCLC & $168(84.0)$ & & \\
\hline SClC & $32(16.0)$ & & \\
\hline \multicolumn{4}{|l|}{ Stage (TNM), n (\%) } \\
\hline l or 11 & $68(34.0)$ & & \\
\hline 111 or IV & $132(66.0)$ & & \\
\hline
\end{tabular}

NSCLC: non-small cell lung cancer; SCLC: small cell lung cancer; and TNM: tumor-node-metastasis. ${ }^{*}$ chi-square test. 
Table 2 - Genotypes of CYP1A1*2A polymorphisms.

\begin{tabular}{|c|c|c|c|c|}
\hline $\begin{array}{l}\text { CYP1A } 1 * 2 A \\
\text { genotype }\end{array}$ & $\begin{array}{c}\text { Patients } \\
\mathrm{n}(\%)\end{array}$ & $\begin{array}{c}\text { Controls } \\
\mathrm{n}(\%)\end{array}$ & OR $(95 \% \mathrm{Cl})$ & $p$ \\
\hline $\mathrm{CC}$ & $11(5.5)$ & $9(3.4)$ & $1.39(0.40-4.84)$ & 0.69 \\
\hline $\mathrm{TC}$ & $76(38.0)$ & 94 (35.6) & $1.17(0.70-1.98)$ & 0.99 \\
\hline CC plus TC & $87(43.5)$ & $103(39.0)$ & $0.84(0.51-1.39)$ & 0.49 \\
\hline TT & $113(56.5)$ & $161(61.0)$ & 1.00 (reference) & \\
\hline
\end{tabular}

CC: variant of the $\mathrm{CY} 1 \mathrm{~A} 1{ }^{*} 2 \mathrm{~A}$ gene; $\mathrm{TC}$ : heterozygotic for $\mathrm{CYP} 1 \mathrm{~A} 1{ }^{*} 2 \mathrm{~A}$; $\mathrm{CC}$ plus TC: variant plus heterozygotic for $\mathrm{CYP} 1 \mathrm{~A} 1{ }^{*} 2 \mathrm{~A}$; and TT: wild-type variant of the $\mathrm{CY} 1 \mathrm{~A} 1{ }^{*} 2 \mathrm{~A}$ gene.

ediaminetetraacetic acid-containing tubes. The DNA was extracted using DNAzol TM reagent (Gibco BRL/Life Technologies, Gaithersburg, $\mathrm{MD}, \mathrm{USA}$ ), proteinase $\mathrm{K}$ and lithium chloride.

Each PCR reaction mixture $(50 \mu \mathrm{L})$ contained $200 \mathrm{ng}$ of each primer-sense (5'-GGC TGA GCA ATC TGA CCC TA-3') and antisense (5'-TAG GAG TCT TGT CTC ATG CCT-3')-100 ng of genomic DNA, $1.5 \mathrm{mM}$ of $\mathrm{MgCl}_{2}, 100 \mathrm{mM}$ of each dNTP and $1 \mathrm{U}$ of Taq polymerase (Invitrogen life Technologies, Carlsbad, CA, USA). The reaction involved 35 cycles of incubation at $94^{\circ} \mathrm{C}(30 \mathrm{~s})$, $63^{\circ} \mathrm{C}(1 \mathrm{~min})$ and $72^{\circ} \mathrm{C}(1 \mathrm{~min})$. After an amplified fragment of the expected size (899 bp) had been obtained on an agarose gel, the PCR products were digested overnight with $50 \mathrm{U}$ of the restriction enzyme Mspl (New England Biolabs, Beverly, MA, USA) at $37^{\circ} \mathrm{C}$, generating smaller fragments when there was a mutation. Fragments were evaluated on a $2.5 \%$ agarose gel stained with ethidium bromide. ${ }^{(14)}$

\section{Statistical analysis}

The Hardy-Weinberg equilibrium was tested using the chi-square test for the goodness-of-fit (one degree of freedom) model. Statistical differences between groups were calculated using the chi-square test or Fisher's exact test. Conditional analysis was used to obtain ethnic group, age and gender-adjusted crude odds ratios. All analyses were performed using the statistical package SAS System for Windows, version 8.2 (SAS Institute, Cary, NC, USA).

\section{Results}

Patient and control samples were in HardyWeinberg equilibrium for CYP1A $1{ }^{*} 2 \mathrm{~A}$ gene $\left(\chi^{2}=0.148 ; p=0.76\right.$ and $\chi^{2}=1.12 ; p=0.79$, respectively).

As shown in Table 1, the lung cancer patients were older than were the controls ( $>64$ years: $50.0 \%$ vs. $5.3 \% ; p<0.0001)$, and the proportion of males was greater in the lung cancer group (72.0\% Vs. $28.0 \%$; $p=0.0106)$, as was the proportion of smokers $(89.5 \%$ vs. $32.6 \%$; $p<0.0001)$.

The difference between lung cancer patients and controls in terms of the distribution of CYP1A $1 * 2 A$ polymorphisms was not statistically significant ( $p=0.49$; Table 2$)$. As can be seen in Table 3, there were no statistically significant differences between the two groups for CC plus TC genotype or the TT genotype.

Table 4 shows the unadjusted odds ratios and 95\% Cls for all of the studied variables, calculated using a logistic regression model for CYP $1 A 1^{*} 2 A$ in patients with lung cancer. When we focused specifically on ethnic groups, the CYP1A $1{ }^{*} 2 A$ genotype CC plus TC was found to be more common among the African-Brazilian patients than among the White patients $(\mathrm{OR}=2.93 ; \mathrm{p}=0.02)$.

Table 3 - The CC plus TC genotype and TT genotype in controls and lung cancer patients, by ethnicity.

\begin{tabular}{lccccccc}
\hline \multicolumn{1}{c}{ Ethnicity } & Group & CC plus TC & TT & $n$ & OR & $95 \% \mathrm{Cl}$ & $\mathrm{p}$ \\
\hline African-Brazilian & Patients & 27 & 15 & 42 & 2.03 & $0.81-5.18$ & 0.14 \\
& Controls & 23 & 26 & 49 & & & \\
White & Patients & 60 & 98 & 158 & 1.03 & $0.66-1.61$ & 0.96 \\
& Controls & 80 & 135 & 215 & & & \\
\hline
\end{tabular}

CC plus TC: variant of the $\mathrm{CY} 1 \mathrm{~A} 1{ }^{*} 2 \mathrm{~A}$ gene plus heterozygotic for CYP $1 \mathrm{~A} 1 * 2 \mathrm{~A}$; and TT: wild-type variant of the $\mathrm{CY} 1 \mathrm{~A} 1 * 2 \mathrm{~A}$ gene. 
Table 4 - Demographic data and smoking history correlated with CYP1A1*2A genotypes in patients with lung cancer.

\begin{tabular}{|c|c|c|c|c|c|c|}
\hline Characteristic & CC plus TC & TT & $\begin{array}{c}\text { Patients } \\
(n)\end{array}$ & OR & $95 \% \mathrm{Cl}$ & $p$ \\
\hline \multicolumn{7}{|l|}{ Gender } \\
\hline Male & 60 & 84 & 144 & 0.76 & $0.41-1.42$ & 0.402 \\
\hline Female & 27 & 29 & 56 & & & \\
\hline \multicolumn{7}{|l|}{ Age } \\
\hline$\geq 64$ years & 50 & 61 & 111 & 1.15 & $0.65-2.02$ & 0.623 \\
\hline$<64$ years & 37 & 52 & 89 & & & \\
\hline \multicolumn{7}{|l|}{ Ethnicity } \\
\hline African-Brazilian & 27 & 15 & 42 & 2.93 & $1.44-5.96$ & 0.02 \\
\hline White & 60 & 98 & 158 & & & \\
\hline \multicolumn{7}{|l|}{ Smoking history } \\
\hline$\geq 40$ pack-years & 49 & 76 & 125 & 0.70 & $0.28-1.79$ & \\
\hline < 40 pack-years & 28 & 26 & 54 & 1.18 & $0.43-3.24$ & 0.270 \\
\hline None & 10 & 11 & 21 & & & \\
\hline
\end{tabular}

In the multivariate logistic model, the $\mathrm{CC}$ plus TC genotype was more common among the African-Brazilian patients than among the White patients (adjusted OR $=3.19 ; 95 \%$ $\mathrm{Cl}$ : 1.53-6.65).

We then performed the same univariate logistic regression model analysis for the controls and found no race-related difference in the prevalence of CYP1A1*2A genotypes (Table 5).

\section{Discussion}

In the present study, we have investigated whether the presence of CYP $1 \mathrm{~A} 1{ }^{*} 2 \mathrm{~A}$ polymor- phisms is related to increased lung cancer risk, as well as whether such polymorphisms are correlated with age, gender, ethnic group and smoking history.

Patient and control samples were in HardyWeinberg equilibrium for the polymorphic gene $\mathrm{CYP} 1 \mathrm{~A} 1 * 2 \mathrm{~A}$. Therefore, the controls were considered appropriate for use in evaluating the frequency of that polymorphism in the general population, allowing the comparative analysis with lung cancer patients. The frequencies of the CYP $1 \mathrm{~A} 1 * 2 \mathrm{~A}$ genotypes were similar between the patients and controls. Therefore, a polymor-

Table 5 - Demographic data and smoking correlated with CYP1A1*2A genotypes in controls.

\begin{tabular}{|c|c|c|c|c|c|c|}
\hline Characteristic & CC plus TC & $\mathrm{TT}$ & $\begin{array}{c}\text { Controls } \\
(n)\end{array}$ & $\mathrm{OR}$ & $95 \% \mathrm{Cl}$ & $p$ \\
\hline \multicolumn{7}{|l|}{ Gender } \\
\hline Male & 57 & 103 & 160 & 0.69 & $0.46-1.15$ & 0.161 \\
\hline Female & 46 & 58 & 104 & & & \\
\hline \multicolumn{7}{|l|}{ Age } \\
\hline$\geq 64$ years & 7 & 9 & 16 & 1.49 & $0.79-2.79$ & 0.689 \\
\hline$<64$ years & 96 & 152 & 248 & & & \\
\hline \multicolumn{7}{|l|}{ Ethnicity } \\
\hline African-Brazilian & 23 & 26 & 49 & 1.29 & $0.44-3.41$ & 0.208 \\
\hline White & 80 & 135 & 215 & & & \\
\hline \multicolumn{7}{|l|}{ Smoking } \\
\hline Yes & 30 & 56 & 86 & 0.77 & $0.45-1.31$ & 0.339 \\
\hline No & 73 & 105 & 178 & & & \\
\hline
\end{tabular}

CC plus TC: variant of the $\mathrm{CY} 1 \mathrm{~A} 1{ }^{*} 2 \mathrm{~A}$ gene plus heterozygotic for $\mathrm{CYP} 1 \mathrm{~A} 1{ }^{*} 2 \mathrm{~A}$; and TT: wild-type variant of the $\mathrm{CY} 1 \mathrm{~A} 1^{*} 2 \mathrm{~A}$ gene. 
phism in this gene does not seem to increase the risk of lung cancer in Brazilians.

Ethnic factors have been shown to correlate with the occurrence of lung cancer in many parts of the world. ${ }^{(15-20)}$ In a study conducted in the United States, Gadgeel et al. ${ }^{(21)}$ showed that the incidence of lung cancer was 37\% higher in African-Americans than in Whites.

Homozygosity for CYP1A1 variant alleles has been found to correlate with lung cancer risk among Americans. ${ }^{(22)} \mathrm{A}$ similar risk for lung cancer associated with a single mutated allele in CYP1A1 was found in a population in Chile. ${ }^{(23)}$ Sreeja et al. ${ }^{(7)}$ reported the same correlations in a population in India (OR $=3.2 ; 95 \%$ $\mathrm{Cl}$ : 1.29-7.80), as did Song et al. ${ }^{(24)}$ in a population in China (OR $=2.0 ; 95 \% \mathrm{Cl}: 1.4-2.8)$. It is possible that ethnically distinct patterns of CYP1A1 genotypes offer a partial explanation for discrepancies in the association between $\mathrm{CYP} 1 \mathrm{~A} 1{ }^{*} 2 \mathrm{~A}$ gene polymorphisms and susceptibility to smoking-related lung cancer. It is of note that, among lung cancer patients, CYP1A1 polymorphisms occur in African-Americans at a frequency similar to that observed for Asians. ${ }^{(25)}$ In the present study, we found that, within the lung cancer group, the frequency of the CC plus TC genotype (CYP1A1*2A polymorphism) was higher among the African-Brazilians than among the White Brazilians $(\mathrm{OR}=2.93$; $95 \% \mathrm{Cl}: 1.44-5.96$ and adjusted $\mathrm{OR}=3.19 ; 95 \%$ $\mathrm{Cl}: 1.53-6.65)$.

In conclusion, our results suggest that CYP1A $1{ }^{*} 2 \mathrm{~A}$ gene polymorphisms have no influence on the risk of lung cancer in our Brazilian population as a whole. However, among lung cancer patients, African-Brazilians carry the CYP1A $1{ }^{*} 2 \mathrm{~A}$ genotype CC plus TC more often than do White Brazilians. Our study sample was small, and we therefore could not establish whether carrying this genotype increases the risk of lung cancer in African-Brazilians. Larger studies are needed in order to determine whether the CYP $1 \mathrm{~A} 1 * 2 \mathrm{~A}$ genotype CC plus TC is a cancer-susceptibility allele in individuals of African descent.

\section{References}

1. Hecht SS. Cigarette smoking and lung cancer: chemical mechanisms and approaches to prevention. Lancet Oncol. 2002;3(8):461-9.
2. Duarte RL, Paschoal ME. Molecular markers in lung cancer: prognostic role and relationship to smoking. J Bras Pneumol. 2006;32(1):56-65.

3. Nebert DW, McKinnon RA, Puga A. Human drugmetabolizing enzyme polymorphisms: effects on risk of toxicity and cancer. DNA Cell Biol. 1996;15(4):273-80.

4. Bale AE, Nebert DW, McBride OW. Subchromosomal localization of the dioxin- inducible p1-450 locus (CYP1) and description of two RFLPs detected with a 3' p1-450 cDNA probe. Cytogenet Cell Genet. 1987;46:574-5.

5. Spurr NK, Gough AC, Stevenson K, Wolf CR. Msp-1 polymorphism detected with a cDNA probe for the P-450 1 family on chromosome 15. Nucleic Acids Res. 1987;15(14):5901.

6. Nakachi K, Imai K, Hayashi S, Watanabe J, Kawajiri K. Genetic susceptibility to squamous cell carcinoma of the lung in relation to cigarette smoking dose. Cancer Res. 1991;51(19):5177-80.

7. Sreeja L, Syamala V, Hariharan S, Madhavan J, Devan SC, Ankathil R. Possible risk modification by CYP1A1, GSTM1 and GSTT1 gene polymorphisms in lung cancer susceptibility in a South Indian population. J Hum Genet. 2005;50(12):618-27.

8. Kawajiri K, Eguchi H, Nakachi K, Sekiya T, Yamamoto M. Association of CYP1A1 germ line polymorphisms with mutations of the p53 gene in lung cancer. Cancer Res. 1996;56(1):72-6.

9. Mooney LA, Bell DA, Santella RM, Van Bennekum AM, Ottman R, Paik M, et al. Contribution of genetic and nutritional factors to DNA damage in heavy smokers. Carcinogenesis. 1997;18(3):503-9.

10. Drakoulis N, Cascorbi 1, Brockmöller J, Gross CR, Roots 1. Polymorphisms in the human CYP1A1 gene as susceptibility factors for lung cancer: exon-7 mutation (4889 A to G), and a T to C mutation in the 3'-flanking region. Clin Investig. 1994;72(3):240-8.

11. Garte S, Boffetta P, Caporaso N, Vineis P. Metabolic gene allele nomenclature. Cancer Epidemiol Biomarkers Prev. 2001;10(12):1305-6.

12. Tefre T, Ryberg D, Haugen A, Nebert DW, Skaug V, Brøgger A, et al. Human CYP1A1 (cytochrome P(1)450) gene: lack of association between the Msp 1 restriction fragment length polymorphism and incidence of lung cancer in a Norwegian population. Pharmacogenetics. 1991;1(1):20-5.

13. Taioli E, Ford J, Trachman J, Li Y, Demopoulos R, Garte S. Lung cancer risk and CYP1A1 genotype in African Americans. Carcinogenesis. 1998;19(5):813-7.

14. Cascorbi 1, Brockmöller J, Roots 1. A C4887A polymorphism in exon 7 of human CYP1A1: population frequency, mutation linkages, and impact on lung cancer susceptibility. Cancer Res. 1996;56(21):4965-9.

15. Kelsey KT, Wrensch M, Zuo ZF, Miike R, Wiencke JK. A population-based case-control study of the CYP2D6 and GSTT1 polymorphisms and malignant brain tumors. Pharmacogenetics. 1997;7(6):463-8.

16. Ford JG, Li Y, O'Sullivan MM, Demopoulos R, Garte $\mathrm{S}$, Taioli E, et al. Glutathione S-transferase M1 polymorphism and lung cancer risk in African-Americans. Carcinogenesis. 2000;21(11):1971-5.

17. Oztürk O, lsbir T, Yaylim 1, Kocatürk $\mathrm{Cl}$, Gürses A. GST $\mathrm{M} 1$ and CYP1A1 gene polymorphism and daily fruit consumption in Turkish patients with non-small cell lung carcinomas. In Vivo. 2003;17(6):625-32. 
18. Pinarbasi H, Silig Y, Cetinkaya O, Seyfikli Z, Pinarbasi E. Strong association between the GSTM1-null genotype and lung cancer in a Turkish population. Cancer Genet Cytogenet. 2003;146(2):125-9.

19. Barnholtz-Sloan JS, Chakraborty R, Sellers TA, Schwartz AG. Examining population stratification via individual ancestry estimates versus self-reported race. Cancer Epidemiol Biomarkers Prev. 2005;14(6):1545-51.

20. Cote CG, Celli BR. Pulmonary rehabilitation and the BODE index in COPD. Eur Respir J. 2005;26(4):630-6.

21. Gadgeel SM, Severson RK, Kau Y, Graff J, Weiss LK, Kalemkerian GP. Impact of race in lung cancer: analysis of temporal trends from a surveillance, epidemiology, and end results database. Chest. 2001;120(1):55-63.

22. Xu X, Kelsey KT, Wiencke JK, Wain JC, Christiani DC. Cytochrome P450 CYP1A1 Mspl polymorphism and lung cancer susceptibility. Cancer Epidemiol Biomarkers Prev. 1996;5(9):687-92.

23. Quiñones L, Berthou F, Varela N, Simon B, Gil L, Lucas D. Ethnic susceptibility to lung cancer: differences in CYP2E1, CYP1A1 and GSTM1 genetic polymorphisms between French Caucasian and Chilean populations. Cancer Lett. 1999;141(1-2):167-71.

24. Song N, Tan W, Xing D, lin D. CYP $1 \mathrm{~A} 1$ polymorphism and risk of lung cancer in relation to tobacco smoking: a case-control study in China. Carcinogenesis. 2001;22(1):11-6.

25. Cosma G, Crofts F, Taioli E, Toniolo P, Garte S. Relationship between genotype and function of the human CYP1A1 gene. J Toxicol Environ Health. 1993;40(2-3):309-16.

\section{About the authors}

\section{Helen Naemi Honma}

Biologist. Laboratory of Pulmonology/Oncology, Universidade Estadual de Campinas - Unicamp, State University at Campinas School of Medical Sciences, Campinas, Brazil.

\section{Eduardo Mello De Capitani}

Tenured Professor. Department of Clinical Medicine, Universidade Estadual de Campinas - Unicamp, State University at Campinas School of Medical Sciences, Campinas, Brazil.

\section{Aristóteles de Souza Barbeiro}

Pulmomologist. Universidade Estadual de Campinas - Unicamp, State University at Campinas - School of Medical Sciences Hospital das Clínicas, Campinas, Brazil.

\section{Daniel Botelho Costa}

Researcher. Department of Hematology/Oncology, Beth lsrael Deaconess Medical Center, Harvard Medical School, Boston, MA, USA.

\section{André Morcillo}

Tenured Professor. Department of Pediatrics, Universidade Estadual de Campinas - Unicamp, State University at Campinas School of Medical Sciences, Campinas, Brazil.

\section{Lair Zambon}

Tenured Professor. Department of Clinical Medicine, Universidade Estadual de Campinas - Unicamp, State University at Campinas School of Medical Sciences, Campinas, Brazil. 